\title{
POLYPHENOLS OF RED GRAPES IN WINE AND CONCENTRATES FOR USE IN REHABILITATION TECHNOLOGIES
}

\section{A.V. KUBYSHKIN', A.M. AVIDZBA ${ }^{2}$, V.S. BORISYUK ${ }^{3}$, V.S. STOYANOV3, I.I. FOMOCHKINA ${ }^{1}$, Yu.A. OGAI ${ }^{2}$, I.V. CHERNOUSOVA ${ }^{2}$, G.P. ZAITSEV ${ }^{2}$, T.I. GUGUCHKINA ${ }^{4}$, V.A. MARKOSOV ${ }^{4}$, N.M. AGEEVA ${ }^{4}$, Yu.I. SHRAMKO ${ }^{1}$}

\begin{abstract}
${ }^{1}$ S.I. Georgievskii Medical Academy of V.I. Vernadsky Crimean Federal University, 5/7, bul. Lenina, Simferopol, Republic of Crimea, 295051 Russia, e-mail Kubyshkin_av@mail.ru (corresponding author), scipro@csmu.strace.net, soniashko@mail.ru, yuliana.shramko@yandex.ru;

${ }^{2}$ National Research Institute for Grape and Wine Magarach RAS, Federal Agency of Scientific Organizations, 31, ul. Kirova, Yalta, Republic of Crimea, 298671 Russia, e-mail magarach@rambler.ru, enoant@yandex.ru, chernblack@mail.ru, gorg-83@mail.ru;

${ }_{3}^{3}$ Sanatorium Ai-Petri, 15, sh. Alupkinskoe, pgt Koreiz-1, Yalta, Republic of Crimea, 298671 Russia, e-mail aipetry@mail.ru;

${ }^{4}$ North Caucasian Regional Research Institute of Horticulture and Viticulture, Federal Agency of Scientific Organizations, 39, ul. im. 40-letiya Pobedy, Krasnodar, 350901 Russia, e-mail guguchkina@mail.ru, ageyeva@inbox.ru ORCID:

Kubyshkin A.V. orcid.org/0000-0002-1309-4005

Avidzba A.M. orcid.org/0000-0002-2354-1374

Fomochkina I.I. orcid.org/0000-0003-3065-5748

Ogai Yu.A. orcid.org/0000-0002-7619-0766

The authors declare no conflict of interests

Acknowledgements:

Supported by Russian Ministry of Education (Unique identifier PNI RFMEFI60414X0077 Agreement № 14.604.21.0077) Received November 9, 2016
\end{abstract}

\section{Abstract}

In recent years, as cardiovascular mortality is increasing, the interest in studying the influence of polyphenol-rich grape products (PRGP) on cardiovascular risks is constantly growing. The estimation of a safe and effective dose of PRGP deserves special attention, because an excessive consumption can lead to endothelial dysfunction and oxidative stress. The hygienic and curative properties the young branches of grapevine, leaves, berries, juice and wine are used in traditional medicine for a long time. The curative properties of grapes are known to be due to the presence of biologically active grape polyphenols, which are accumulated in grapeskin, pulp, and seeds, etc. Polyphenols are extracted during alcoholic fermentation and determine the antioxidant status and biological activity of wines and other grape products. Here our objective was to analyze polyphenols in red wine (RW) and extracts from red grapes (EPG) and to compare the influence of fixed concentration of polyphenols on cardiovascular parameters, lipid peroxidation (LPO) and lipid metabolism at ischemic heart disease (IHD) and essential hypertension (EH) in the course of the SPA and resort-based treatment of 259 patients. The clinical trials of therapeutic and prophylactic properties of the experimental samples of red wine and extracts of polyphenols from red grapes showed that the use of these products as part of complex therapy contributes to the significant improvement of lipid metabolism, i.e. total cholesterol was reduced by $22 \%$ and the atherogenic index decreased by $10 \%$, to a reduced free radical oxidation (end products of LPO decreased by $30.3 \%$ when using the RW, and by $32.3 \%$ in case of EPG), as compared to the patients from control groups who were not provided with PRGP in addition to a standard rehabilitation. The normalization of cardiovascular indexes also occurred. In the most patients, the tolerance to physical activity increased by $22.4 \%$ compared to the control group. The clinical effect was achieved during a 14-day course at a daily dose of $3.6 \mathrm{ml} / \mathrm{kg}$ for RW, and of $0.45 \mathrm{ml} / \mathrm{kg}$ for EPG. The mechanisms of action of these polyphenolic products and the possibility of their use for primary and secondary prevention of disorders in patients with cardiovascular disease are discussed.

Keywords: grape polyphenols, antioxidant activity, ischemic heart disease, hypertension, red wine, extract of polyphenols from red grapes

Products of grape processing with a high content of polyphenols obtained from grape pulp exhibit unique bioactive properties and may be used in pharmacology [1-3]. Red grape wines containing on average $2.5 \mathrm{~g} / \mathrm{dm}^{3}$ of poly- 
phenols, are recommended at a dose of 150-300 ml/day by American nutrition experts for reducing risk of cardiovascular diseases [4] that is explained by a beneficial effect on cardiometabolic factors [5-7]. Cardioprotection effect of polyphenols is associated with the vitamin $\mathrm{P}$ activity of the tannin-catechin complex that enhances the strength of capillary walls [3], the similar effect of anthocyans [3] and fortifying effect of procyanidins which inhibit collagen-destructive enzymes and reduce aortic elastin-associated cholesterol [3]. Antioxidative activity of wine correlates to the content of polyphenols in grapes, and there is a synergy of effects of polyphenols in the product $[8,9]$.

Controlled and regular wine consumption is considered favorable for mitigating a threat of cardiovascular accidents [5-7, 10], although alcohol at doses of more than $31 \mathrm{ml} /$ day may negatively affect cardiovascular system [1113]. Therefore, it is necessary to identify effective and safe doses of wines and other polyphenol-enriched products of grape processing. It should be noted that the content of polyphenols in these products is not controlled by domestic and foreign standards. Such an uncertainty makes it difficult to assess grapes and determine quality requirements for primary producers and breeders, as well as elaborate regulations for manufacturing and introducing the functional products in rehabilitation.

Polyphenols of red grapes in wines and concentrates are composed of two primary groups of flavonoid and non-flavonoid substances [2, 8, 14-16]. Monomeric flavonoids are glycosides of anthocyans (delphinidin, malvidin, cyanidin, petunidin), quercetin and its glycoside, (+)-D-catechin, (-)-epicatechin. Oligomeric flavonoids (procyanidins) consist of several (up to six) condensed catechin units (catechin, epicatechin and their dimers); polymeric procyanidins contain seven and more catechin units. Oligomeric and polymeric forms of flavonoids constitute a greater labile part of total polyphenols in bioactive red wines and concentrates. Among non-flavonoid polyphenols, there are hydroxybenzoic acids (gallic, syringic) and hydroxycinnamic acids (caftaric, cautaric), chlorogenic acid and trans-resveratrol [16].

Clinical studies of patients with chronic diseases have revealed some differences in the effectiveness of enotherapy [17, 18]. In particular, it has been found that the cardioprotection activity depends on the structure and concentration of polyphenols, their bioavailability, and patients' diet and individual characteristics. Thus, there is grate necessity for more representative clinical studies of effects of polyphenols contained in red wines and concentrates.

We are the first who developed formulae and manufacturing technologies for grape wines and concentrates having identical compositions and amounts of polyphenols for therapeutic application and estimated experimentally their cardioprotection activity.

The objective of the study was to obtain products for enotherapy and concentrates with standardized contents of polyphenols using red grapes, and to investigate their efficacy in the sanatorium-and-spa treatment (SST) of cardiovascular diseases.

Technique. Red table wine Zdorovye was produced from mature Saperavi grape with total sugars of at least $170 \mathrm{~g} / \mathrm{dm}^{3}$. Fermentation with floating cap was performed in a vinificator at $25-27{ }^{\circ} \mathrm{C}$ for 4.5 days with a control for concentration of total polyphenols in the substrate ready for bottling (at least $2.5 \mathrm{~g} / \mathrm{dm}^{3}$ ). In preparing an extract of polyphenols, fermented Cabernet Sauvignon grape pulp undergone a water-alcohol extraxtion with further dealcoholization under vacuum to the ethanol content of $10.5-15.0 \mathrm{vol} \%$ and the concentration of total phenolic substances of at least $20.0 \mathrm{~g} / \mathrm{dm}^{3}$. Experimental products were produced from grapes harvested in 2015. Samples of commercial wines from red 
grapes (Cabernet Sauvignon, Merlot and Saperavi; vintage of 2014) were used to compare the polyphenol composition.

The composition and quantity of polyphenols were analyzed by the highperformance liquid chromatography (HPLC) using an Agilent 1100 chromatograph with a diode array detector (Agilent Technologies, USA). Chromatographic column Zorbax SB-C18 $(2.1 \times 150 \mathrm{~mm})$ filled with silica gel with bonded octadecylsilyl phase (sorbent particle size of $3.5 \mu \mathrm{m}$ ) was used for separation. The eluent consisted of A (methanol) and B (0.6\% trifluoroacetic acid aqueous solution). Chromatography was performed in the gradient mode with varying the content of component $\mathrm{B}$ as follows: $0 \mathrm{~min}-8 \%$; 0-8 $\mathrm{min}-8-38 \%$; 8-24 $\mathrm{min}-$ $38-100 \%$; $24-30 \mathrm{~min}-100 \%$; eluent flow rate was $0.25 \mathrm{ml} / \mathrm{min}$; injection volume $1 \mu$ l. Separation of fractions was recorded at $280 \mathrm{~nm}$ for gallic acid, (+)-Dcatechin, (-)-epicatechin and procyanidins, at $313 \mathrm{~nm}$ for derivatives of hydroxycinnamic acids, at $371 \mathrm{~nm}$ for quercetin, and at $525 \mathrm{~nm}$ for anthocyans. For identification of substances, retention time was compared with that of standards [19, 20]; for quantitation we used calibration curves for individual substance solutions. Aanthocyan contents were expressed as equivalent of malvidin3-O-glucoside chloride, caftaric acid - as equivalent of caffeic acid, polymeric and oligomeric procyanidins - as equivalent of $(+)$-D-catechin. Gallic acid, caffeic acid, (+)-D-catechin, malvidin-3-O-glucoside chloride, quercetin dihydrate, isoquercitrin (Fluka Chemie AG, Switzerland) and trans-resveratrol, (-)epicatechin, syringic acid (Sigma-Aldrich, Switzerland) served as standards. All measurements were made in 3 replicates. For the consistency of results, amounts of substances were expressed in milligrams per $1 \mathrm{~kg}$ of dry husk weight.

Mass concentration of phenolic substances in the products studied was identified colorimetrically. To an aliquot of $1 \mathrm{~cm}^{3}$ of a sample diluted to $10^{-2}$ the Folin-Ciocalteu reagent $\left(1 \mathrm{~cm}^{3}\right)$ and sodium carbonate $\left(10 \mathrm{~cm}^{3}\right)$ were added, then the mixture was diluted to $100 \mathrm{~cm}^{3}$ with distilled water and allowed at room temperature $\left(20 \pm 0.5^{\circ} \mathrm{C}\right)$ for $30-40 \mathrm{~min}$. Optical density was measured against the control in a cuvette with $10 \mathrm{~mm}$ optical path length at $\lambda=670 \mathrm{~nm}$. The mass concentration of phenolic substances $\left(C, \mathrm{mg} / \mathrm{dm}^{3}\right.$ expressed as equivalent of gallic acid) was calculated using the calibration curve as $\mathrm{C}=\mathrm{F} \times \mathrm{OD}$, where, $\mathrm{C}$ is mass concentration of phenolic substances, $\mathrm{F}$ is dilution factor, $\mathrm{OD}$ is optical density. The calibration curve was constructed as described [21]. The arithmetical mean of two measurements with the allowable discrepancy of no more than $33 \mathrm{mg} / \mathrm{dm}^{3}$ for the range of $3000-20000 \mathrm{mg} / \mathrm{dm}^{3}$ was taken as a final result. The measurement error limit for mass concentration of phenolic substances at $\mathrm{P}=0.95$ for this range was $\pm 39 \mathrm{mg} / \mathrm{dm}^{3}$. The measurements were made in 3 replicates. Antioxidative activity of samples was assessed amperometrically with trolox antioxidant as standard (Tsvet Yauza 01-AA apparatus, Khimavtomatika, Russia) [22].

Clinical studies (Ai-Petri sanatorium, May-October 2016; protocol approved by a local ethics committee) involved 259 patients aged from 30 to 80 years old with ischemic heart disease (IHD, $n=96$ ) and hypertension (HT, $n=163$ ). Among them, 40 patients without carbohydrate metabolism disorders, comparable in age and sex, were control groups (IHD, $n=20$; HT, $n=20$ ). The diseases were diagnosed for 2-15 years, in IHD there was a stable effort angina of no more than Functional Class III (FC) in a treadmill test (as recommended by the Canadian Cardiovascular Society), chronic heart failure (CHF) of no more than Stage IIa (according to the classification of Vasilenko-Strazhesko), CHF FC I-III. All enrolled patients signed the informed participation consent forms. The treatment group of patients with IHD included $34(44.7 \%)$ males and $42(55.3 \%)$ females, with a median age of 61.0 years old (46.0 and 77.0, respectively). A total of 47 pa- 
tiens with IHD had stable angina without myocardial infarction; the average FC of angina was $1.98 \pm 0.60 ; 24$ patients with IHD had HT as a concomitant disease. The treatment group with HT (grade I-II arterial hypertension) included 105 $(73.4 \%)$ males and $38(26.6 \%)$ females, with a median age of 57.5 years old (37.0; 75.0); 23 patients with HT had IHD as a concomitant disease. Initially, the treatment and control groups with the same disease had no differences in significant parameters $(\mathrm{p}<0.05)$.

All the groups were prescribed with similar non-drug treatment (climatotherapy, exercise therapy, massage, balneotherapy, instrumental physiotherapy, etc.) [18] with regard to individual indications and medicines according to the standards approved: isosorbide dinitrate $20 \mathrm{mg}$ twice daily (in the IHD group), lisinopril $20 \mathrm{mg}$ once daily (in the HT group), acetylsalicylic acid $75 \mathrm{mg}$ once daily, amlodipine $5 \mathrm{mg}$ once daily, bisoprolol $2.5-5.0 \mathrm{mg}$ once daily, atorvastatin $10 \mathrm{mg}$ once daily. In the treatment groups, daily intake of polyphenolic products of grape processing (PPGP) (10 mg of total polyphenols per $1 \mathrm{~kg}$ of body weight) as wine Zdorovye $(3.6 \mathrm{ml} / \mathrm{kg}$ per day) or polyphenol concentrate $(0.45 \mathrm{ml} / \mathrm{kg}$ per day $)$ were added to dinner and supper diets for a 14-day course. No PPGPs were given to the patients in the control groups.

Examinations at the beginning and end of the treatment course (day 0 and day 14) included the assessment of complaints, arterial blood pressure (ABP) dynamics by N.S. Korotkov's method, functional status of cardiovascular and respiratory systems (spirographic, rheographic, electroencephalographic and electrocardiographic indices) using DKh-NT Poli-SPEKTR+ diagnostic suite (Spektromed-Ukraine, Kharkov), hemodynamic cardiac function, i.e. stroke (SVB) and minute volume of blood (MVB), total peripheral resistance (TPR) and exercise tolerance (using the treadmill test). Hematologic study included complete blood count, glucose analysis, blood chemistry, i.e. C-reactive protein, lipid profile, total bilirubin, diene conjugates (DC), determination of prothrombin index (PTI) and fibrinogen. Concentration of C-reactive protein was determined by the enzyme-linked immunosorbent assay [23], for other hemostatic profile Technology-Standard kit (Russia) was used. Lipid peroxidation and blood antioxidant activity of were estimated [24].

The data was analyzed by variation statistics methods using the MannWhitney U-test. The mean $(M)$, standard deviations $( \pm \sigma)$, medians $(M e)$ and quartiles $\left(\mathrm{Q}_{25} \%, \mathrm{Q}_{75} \%\right)$ are provided. Differences among the values were considered statistically significant at $\mathrm{p}<0.05$.

Results. Polyphenols in wines and concentrates produced from Cabernet Sauvignon, Merlot and Saperavi red grapes (originated from commercial vineyards in various southern regions of Russia) were represented by groups of flavonoid and non-flavonoid substances in the monomeric, oligomeric and polymeric forms that was consistent with the literature data [2, 4]. Trans-resveratrol was found in neither commercial nor experimental samples, or it was detected in concentrations less than $1.0 \mathrm{mg} / \mathrm{dm}^{3}$ that was likely associated with seasons of 2014-2015 good for winegrowing and winemaking. Integrated indices for polyphenols determined by the HPLC and using the Folin-Ciocalteu reagent, were different, however, the antioxidant activity characterizing the potential of biological activity varied in proportion to the content of polyphenols in wines and concentrates, as noted previously [8).

Experimental samples of red wine used in the clinical studies contained at least $2.5 \mathrm{~g} / \mathrm{dm}^{3}$ of polyphenols, and those of concentrate (extract of grape polyphenols) contained at least $20.0 \mathrm{~g} / \mathrm{dm}^{3}$ of polyphenols, i.e. the samples were identical to commercial products in composition and concentration of polyphenols (Table 1). 
1. Composition of polyphenols in commercial and experimental samples of the medicinal wine and concentrates produced from red grapes $(M \pm \sigma)$

\begin{tabular}{|c|c|c|c|c|c|c|c|c|c|}
\hline \multicolumn{8}{|c|}{ Commercial } & \multicolumn{2}{|c|}{ Experimental } \\
\hline 1 & 2 & 3 & 4 & 5 & 6 & 7 & 8 & 9 & 10 \\
\hline \multicolumn{10}{|c|}{ Ant hoc y an s, g/dm 3} \\
\hline $20.3 \pm 0.4$ & $23.8 \pm 0.5$ & $23.4 \pm 0.6$ & $133.3 \pm 2.7$ & $\begin{array}{r}\text { Total } \\
167.5 \pm 3.8 \\
\text { F } 1 \text { a v o } \\
\text { Ouercetin- }\end{array}$ & $\begin{array}{l}\text { athocyans } \\
556.2 \pm 12.4 \\
\text { e s, g/dm } \\
\text {-O-glycosid }\end{array}$ & $18.9 \pm 0.4$ & $28.5 \pm 0.6$ & $22.8 \pm 0.6$ & $235.1 \pm 7.5$ \\
\hline $8.5 \pm 0.2$ & $15.9 \pm 0.3$ & $11.5 \pm 0.3$ & $15.7 \pm 0.3$ & $36.9 \pm 0.8$ & $9.8 \pm 0.2$ & $3.1 \pm 0.1$ & $3.5 \pm 0.1$ & $19.0 \pm 0.1$ & $17.4 \pm 0.6$ \\
\hline \multicolumn{10}{|c|}{ Quercetin } \\
\hline $2.8 \pm 0.1$ & $1.6 \pm 0.03$ & $1.2 \pm 0.03$ & $0.3 \pm 0.1$ & $4.1 \pm 0.1$ & $0.7 \pm 0.2$ & $49.6 \pm 1.1$ & $81.2 \pm 1.1$ & $3.4 \pm 0.1$ & $5.8 \pm 0.2$ \\
\hline \multicolumn{10}{|c|}{$\begin{array}{c}\mathrm{F} 1 \text { a } \vee \text { a } \mathrm{n}-3-\mathrm{o} 1 \mathrm{~s}, \mathrm{~g} / \mathrm{dm}^{3} \\
(+)-D \text {-catechin }\end{array}$} \\
\hline $34.7 \pm 0.7$ & $44.8 \pm 0.9$ & $26.8 \pm 0.6$ & $60.8 \pm 1.2$ & $83.5 \pm 1.9$ & $58.6 \pm 4.0$ & $177.6 \pm 4.0$ & $208.5 \pm 5.1$ & $18.4 \pm 0.4$ & $880.3 \pm 28.1$ \\
\hline \multicolumn{10}{|c|}{ (-)-Epicatechin } \\
\hline \multirow{2}{*}{\multicolumn{10}{|c|}{$\begin{array}{c}\mathrm{O} \times \mathrm{y} \text { c i n } \mathrm{na} \mathrm{m} \text { i c a c i d s, } \mathrm{g} / \mathrm{dm}^{3} \\
\text { Caftaric acid }\end{array}$}} \\
\hline & & & & & & & & & \\
\hline $45.6 \pm 0.9$ & $58.0 \pm 1.1$ & $44.3 \pm 1.1$ & $29.9 \pm 0.6$ & $52.7 \pm 1.1$ & $69.6 \pm 1.6$ & $11.7 \pm 0.3$ & $16.9 \pm 0.4$ & $149.8 \pm 3.7$ & $12.1 \pm 0.4$ \\
\hline \multicolumn{10}{|c|}{ Cautaric acid } \\
\hline $7.5 \pm 0.2$ & $10.0 \pm 0.2$ & $7.4 \pm 0.2$ & $3.5 \pm 0.1$ & $5.4 \pm 0.1$ & $11.8 \pm 0.3$ & $1.8 \pm 0.0$ & $2.4 \pm 0.1$ & $5.6 \pm 0.1$ & $3.4 \pm 0.1$ \\
\hline \multicolumn{10}{|c|}{$\begin{array}{c}\mathrm{O} \times \mathrm{y} b \text { e } \mathrm{nz} \text { o i c a c i d s, } \mathrm{g} / \mathrm{dm}^{3} \\
\text { Gallic acid }\end{array}$} \\
\hline $39.3 \pm 0.8$ & $42.6 \pm 0.8$ & $33.8 \pm 0.8$ & $78.1 \pm 1.6$ & $67.8 \pm 1.5$ & $63.8 \pm 1.4$ & $341.1 \pm 7.7$ & $465.2 \pm 11.3$ & $66.0 \pm 1.6$ & $127.3 \pm 4.1$ \\
\hline $7.0 \pm 0.1$ & $5.3 \pm 0.1$ & $9.0 \pm 0.2$ & $8.0 \pm 0.2$ & $4.0 \pm 0.1$ & $4.3 \pm 0.1$ & $22.6 \pm 0.5$ & $26.2 \pm 0.6$ & $11.7 \pm 0.3$ & $5.3 \pm 0.2$ \\
\hline \multicolumn{10}{|c|}{$\begin{array}{c}\mathrm{Pro} \text { a } \mathrm{n} \text { th o c y a } \mathrm{n} \text { i } \mathrm{d} \text { i } \mathrm{ns}, \mathrm{g} / \mathrm{dm}^{3} \\
\text { Oligomeric proanthocyanidins }\end{array}$} \\
\hline $187 \pm 4$ & $222 \pm 4$ & $200 \pm 5$ & $221 \pm 5$ & $222 \pm 0$ & $212 \pm 5$ & $603 \pm 14$ & $1614 \pm 39$ & $319 \pm 8$ & $1625 \pm 52$ \\
\hline \multicolumn{10}{|c|}{ Polymeric proanthocyanidins, $\mathrm{g} / \mathrm{dm}^{3}$} \\
\hline $3045 \pm 61$ & $3723 \pm 73$ & $3525 \pm 84$ & $2068 \pm 42$ & $2072 \pm 47$ & $2380 \pm 53$ & $28155 \pm 634$ & $38436 \pm 932$ & $4670 \pm 114$ & $39943 \pm 127$ \\
\hline \multicolumn{10}{|c|}{$\begin{array}{c}\text { I } \mathrm{n} \mathrm{t} \text { e } \mathrm{g} \text { a t e d } \text { i } \mathrm{nd} \text { ice } \mathrm{s} \\
\text { Total phenolic substances (by } H P L C), \mathrm{g} / \mathrm{dm}^{3}\end{array}$} \\
\hline $3.43 \pm 0.10$ & $4.20 \pm 0.10$ & $3.91 \pm 0.10$ & $2.67 \pm 0.50$ & $2.79 \pm 0.06$ & $3.44 \pm 0.08$ & $29.50 \pm 0.70$ & $41.01 \pm 1.00$ & $5.30 \pm 0.10$ & $43.30 \pm 1.40$ \\
\hline \multicolumn{10}{|c|}{ Total phenolic substances (by Folin-Ciocalteu), g/ $\mathrm{dm}^{3}$} \\
\hline \multicolumn{9}{|c|}{ Antioxidant activity (trolox), $\mathrm{g} / \mathrm{dm}^{3}$} & $21.50 \pm 0.80$ \\
\hline $2.36 \pm 0.06$ & $2.75 \pm 0.07$ & $2.38 \pm 0.70$ & $2.38 \pm 0.70$ & $2.49 \pm 0.06$ & $2.69 \pm 0.06$ & $24.72 \pm 0.73$ & $36.48 \pm 0.92$ & $1.72 \pm 0.10$ & $33.74 \pm 1.20$ \\
\hline $\begin{array}{l}\text { N o te. Wi } \\
\text { peravi (Ma } \\
\text { Premium; } \\
\text { gnon varie } \\
\text { raphy. }\end{array}$ & $\begin{array}{l}\text { ne brand } \\
\text { ssandra); } \\
9-\text { red } \\
\text { y); the s }\end{array}$ & $\begin{array}{l}\text { ind appel } \\
\text { - Cabe } \\
\text { ble wine } \\
\text { ples are }\end{array}$ & $\begin{array}{l}\text { lons (grap } \\
\text { t, } 5-\mathrm{N} \\
\text { lorovje ( } \\
\text { scribed in }\end{array}$ & $\begin{array}{l}\text { ariety geo } \\
\text { lot, } 6-5 \\
\text { eravy vari }\end{array}$ & $\begin{array}{l}\text { aphical it } \\
\text { peravi (K } \\
\text { y), } 10-\end{array}$ & $\begin{array}{l}\text { ication): } \\
\text { an); conc } \\
\text { xtract of }\end{array}$ & $\begin{array}{l}\text { - Caberne } \\
\text { entrates: } 7 \\
\text { rape polyph }\end{array}$ & $\begin{array}{l}\text { t, } 2-\mathrm{Me} \\
- \text { Enoant, } \\
\text { tenols (Cal }\end{array}$ & $\begin{array}{l}\text { lot, } 3-\text { Sa- } \\
8-\text { Enoant } \\
\text { ernet Sauvi- }\end{array}$ \\
\hline
\end{tabular}

The experimental samples have passed clinical testing in the sanatorium. Initially, complaints in the IHD groups generally included typical angina attacks $(78.7 \%)$, decrease in memory $(68.2 \%)$, rapid fatigue $(62.4 \%)$, palpitation $(36.1 \%)$, headache $(34.6 \%)$, dizziness $(30.5 \%)$. After the SST course with PPGP intake, the number of angina attacks reduced almost twice in $84.4 \%$ of patients $(\mathrm{p}<0.05)$. In $24.3 \%$ of patients the angina FC changed from II to I by the end of the treatment course. The majority of patients $(87.3 \%)$ showed decreased fatigue and increased exercise tolerance: the permissible exercise stress increased by $22.4 \%(\mathrm{p}=0.002)$, and the recovery time decreased by $16.4 \%(p=0.01)$. Positive dynamics and clinical effectiveness of the concentrate and the medicinal wine did not differ. Efficacy of the basic treatment course was somewhat lower: cardiac pains decreased only in $52.7 \%$ of patients, palpitation complaints decreased in $34.2 \%$ of patients, fatigue reduced in $55 \%$ of patients. A number of clinical symptoms reduced or disappeared, with improving general condition, in the majority $(83 \%)$ of patients with HT in the treatment group who received the PPGP. In the control group (basic SST course), the clinical symptoms and complaints decreased only in $44 \%$ of patients.

Positive effects of PPGP were observed in IHD and HT by objective parameters characterizing the cardiovascular system status (Table 2). 
2. Dynamics of heart rate (HR), systolic and diastolic blood pressure (SBD and DBD) in patients with ischemic heart disease and hypertension after the sanatorium-and-spa treatment course with administration of products of red grape processing with high content of polyphenols

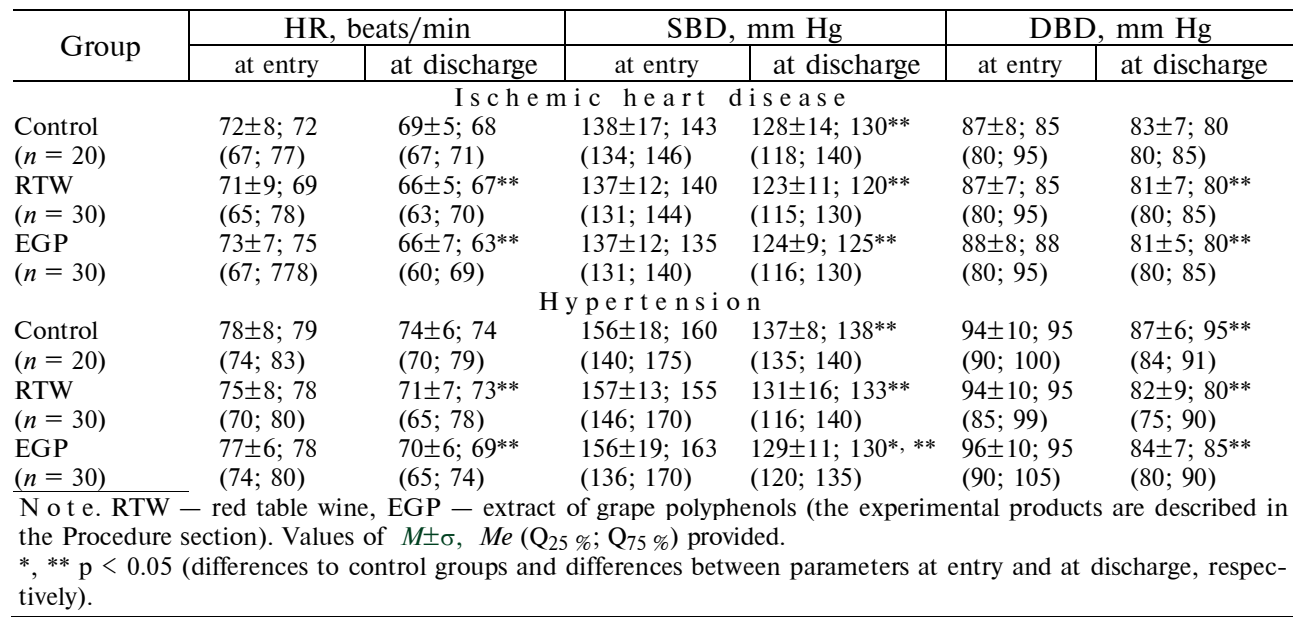

Furthermore, the IHD and HT groups reported the positive effect of PPGP on metabolism. So, the decrease in total cholesterol after administration of PPGP was more significant $(\mathrm{p}<0.05)$ than that in the control group. The fact that the administration of PPGP allowed the improvement of some lipid metabolism indices which were especially disturbed in patients with IHD was an additional confirmation of the efficacy of polyphenols in its normalization ("French paradox").

Blood chemistry parameters (glucose level, total bilirubin, PTI) in the IHD and HT groups did not differ significantly at entry and at discharge and were essentially independent of the PPGP administration. SST in conjunction with PPGP contributed to reduction in C-reactive protein concentration (to less than $2.6 \mathrm{mg} / \mathrm{l}$ in all the groups) that was indicative of the suppression of subclinical inflammation and reduced risk of vascular complications. Efficacy of the medicinal wine and the extract of grape polyphenols was comparable to and exceeded that of the basic SST course.

3. Some lipid peroxidation indices in patients with ischemic heart disease and hypertension after the sanatorium-and-spa treatment course with administration of products of red grape processing with high polyphenol content

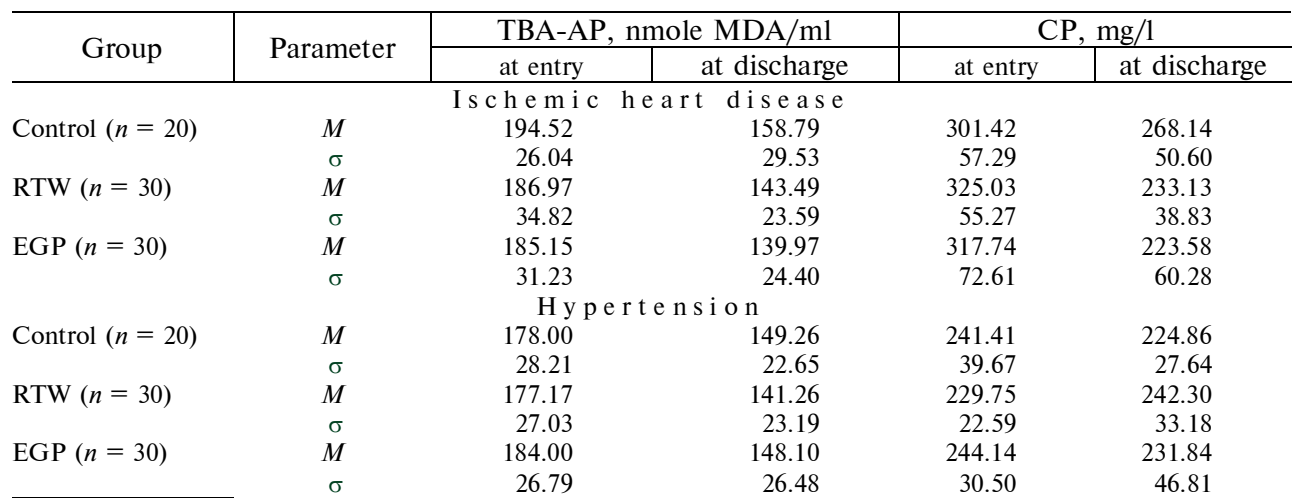

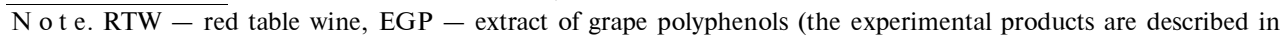
the Procedure section); TBA-AP - active products of thiobarbituric acid, MDA - malondialdehyde, CP - ceruloplasmin. Differences with the control are statistically significant at $\mathrm{p}<0.05$.

As to oxidant-antioxidant homeostasis (Table 3), in IHD and HT, 
PPGPs helped reduce free-radical oxidation that was evidenced by the decrease in number of primary and secondary lipid peroxidation products and the reactivation of antioxidative enzymes.

Hence, the PPGPs as a part of a combined therapy for patients with HT and IHD both have the hypotensive action and improve the lipid metabolism, as well as the activity of the antioxidant system. It should be noted that the PPGPs helped improve the health status in patients with IHD to a greater extent than in those with HT. Central hemodynamics was improved in patients with both diseases.

Thus, the developed technology for manufacturing products from red grapes provides a standardized content of biologically active polyphenols. It has been found out that the products (red table wine Zdorovye and extract of polyphenols) have a curative effect in ischemic heart disease and hypertension and may be used in rehabilitation in addition to the basic sanatorium-and-spa treatment. The therapeutic dose shall correspond to known long-term performance of the total polyphenols and be about $3.6 \mathrm{ml} / \mathrm{kg}$ per day in enotherapy, and about $0.45 \mathrm{ml} / \mathrm{kg}$ per day for the extract of polyphenols (14-day course). For optimization of technologies for sanatorium-and-spa treatment and rehabilitation, the dosages should be further specified.

\section{REFERENCES}

1. Mo n t i n' y a k M. Sekrety zdorovogo pitaniya [Secrets of a healthy diet]. Moscow, 2006 (in Russ.).

2. $\quad \mathrm{Og}$ a i Yu.A. Vinogradarstvo $i$ vinodelie, 2000, 1: 37-38 (in Russ.).

3. Zagaiko A.L., Krasil'nikova O.A., Kravchenko A.B., Voloshchenk o M.V., O g a i Yu.A. Biologicheski aktivnye veshchestva vinograda $i$ zdorov'e [Bioactive substances of grape and human health benefits]. A.L. Zagaiko (ed.). Khar'kov, 2012 (in Russ.).

4. Ha a I.C., To aldo I.M., de Go is J.S., B orges D.L., P et kowicz C.L., Bor dignon-Luiz M.T. Phytochemicals, monosaccharides and elemental composition of the non-pomace constituent of organic and conventional grape juices (Vitis labrusca L.): Effect of drying on the bioactive content. Plant Foods Hum. Nutr., 2016, 71(4): 422-528 (doi: 10.1007/s11130016-0579-9).

5. Ronksley P.E., Brien S.E., Turner B.J., Muka mal K.J., Ghali W.A. Association of alcohol consumption with selected cardiovascular disease outcomes: a systematic review and meta-analysis. BMJ, 2011, 342: d671 (doi: 10.1136/bmj.d671).

6. Shevchenko O., Mishnev O., Shevchenko A., Trusov O., Slastnikova I. Ishemicheskaya bolezn' serdtsa [Cardiac ischemia]. Moscow, 2005 (in Russ.).

7. B a d i mon L., Vila h u r G. LDL-cholesterol versus HDL-cholesterol in the atherosclerotic plaque: inflammatory resolution versus thrombotic chaos. Ann. NY Acad. Sci., 2012, 1254: 1832 (doi: 10.1111/j.1749-6632.2012.06480.x).

8. Avidzba A., Kubyshkin A., Guguchkina T., Markosov V., Katsev A., Naumova N., Shramko Yu., Zaitsev G., Chernousova I., Ogai Yu., Fom o c h k i n a I. Voprosy pitaniya, 2016, 85(1): 99-110 (in Russ.).

9. Xiang L., Xiao L., Wang Y., Li H., Huang Z., He X. Health benefits of wine: don't expect resveratrol too much. Food Chem., 2014, 156: 258-263 (doi: 10.1016/j.foodchem.2014.01.006).

10. Pie poli M.F., Hoes A.W., Agewall S., Albus C., Brotons C., Catapano A.L. et al. European Guidelines on cardiovascular disease prevention in clinical practice: the Sixth Joint Task Force of the European Society of Cardiology and Other Societies on Cardiovascular Disease Prevention in Clinical Practice (constituted by representatives of 10 societies and by invited experts): developed with the special contribution of the European Association for Cardiovascular Prevention \& Rehabilitation (EACPR). Eur. Heart J., 2016 37(29): 2315-2381 (doi: 10.1093/eurheartj/ehw106).

11. Mori T.A., B urke V., B e ili n L.J., Puddey I.B. Randomized controlled intervention of the effects of alcohol on blood pressure in premenopausal women. Hypertension, 2015; 66(3): 517-523 (doi: 10.1161/HYPERTENSIONAHA.115.05773).

12. Muka mal K. Alcohol intake and noncoronary cardiovascular diseases. Ann. Epidemiol., 2007, 17(5): S8-S12 (doi: 10.1016/j.annepidem.2007.01.003).

13. Wu D., C e d e rb a u m A.I. Alcohol, oxidative stress, and free radical damage. Alcohol Res. Health, 2003, 27(4): 277-284 (PMID: 15540798).

14. Quideau S., Deffieux D., Douat-Cas assus C., Pouységu L. Plant polyphenols: chemical properties, biological activities, and synthesis. Angew. Chem. Int. Ed., 2011, 
50(3): 586-621 (doi: 10.1002/anie.201000044).

15. G a ragus o I., N a rd i n i M. Polyphenols content, phenolics profile and antioxidant activity of organic red wines produced without sulfur dioxide/sulfites addition in comparison to conventional red wines. Food Chem., 2015, 179: 336-342 (doi: 10.1016/j.foodchem.2015.01.144).

16. O g a i Yu.A., A l e k s e v a L.M., S i k a z a n O.M., K a t r i ch L.I. Materialy konferentsii «Biologicheski aktivnye prirodnye soedineniya vinograda: gigienicheskie i meditsinskie effekty primeneniya produktov s vysokim soderzhaniem polifenolov vinograda» [Proc. Conf. «Grape natural bioactive substances of grape: sanitary and curative effects of high-polyphenol-based products»]. Simferopol', 2005, V. 41, Part 1: 14-20 (in Russ.).

17. Apostolidou C., Adamopoulos K., Lymperaki E., Iliadis S., Papap re ponis P., Kourtidou-Papadeli C. Cardiovascular risk and benefits from antioxidant dietary intervention with red wine in asymptomatic hypercholesterolemics. Clin. Nutr. ESPEN, 2015, 10(6): e224-e233 (doi: 10.1016/j.clnesp.2015.08.001).

18. Gepner Y., Golan R., Harman-B o e hm I., Iris Shai L. Effects of initiating moderate alcohol intake on cardiometabolic risk in adults with type 2 diabetes: a 2-year randomized, controlled trial. Ann. Intern. Med., 2015, 163(8): 569-579 (doi: 10.7326/M14-1650).

19. W a ng R., S u n Q., Chang Q. Soil types effect on grape and wine composition in Helan Mountain area of Ningxia. PLoS ONE, 2015, 10(2): e0116690 (doi: 10.1371/journal.pone.0116690).

20. Mulero J., Martínez G., Oliva J., Cermeco S., Cayuela J.M., Zafrilla P., Martínez-Ca chá A., B a rba A. Phenolic compounds and antioxidant activity of red wine made from grapes treated with different fungicides. Food Chem., 2015, 180: 25-31 (doi: 10.1016/j.foodchem.2015.01.141).

21. R.4.1.1672-03 Rukovodstvo po metodam kontrolya kachestva i bezopasnosti biologicheski aktivnykh dobavok $k$ pishche [Quality and safety control of bioactive food additives - guidelines. R.4.1.1672-03]. Moscow, 2003 (in Russ.).

22. GOST R 54037-2010 Produkty pishchevye. Opredelenie soderzhaniya vodorastvorimykh antioksidantov amperometricheskim metodom $v$ ovoshchakh, fruktakh, produktakh ikh pererabotki, alkogol'nykh $i$ bezalkogol'nykh napitkakh [RF State Standard R 54037-2010 Foodstuffs. Amperometric estimation of water-soluble antioxidants in vegetable and fruit products, non-alcoholic and alcoholic drinks]. Moscow, 2010 (in Russ.).

23. Highton J., Hessian P. A solid-phase enzyme immunoassay for C-reactive protein: clinical value and the effect of rheumatoid factor. J. Immunol. Methods, 1984, 68: 185-192.

24. Vladi mirov Yu.A., A r chak ov A.I. Perekisnoe okislenie lipidov v biologicheskikh membranakh [Lipid peroxidation in biomembranes]. Moscow, 1972 (in Russ.). 